\section{BP Conservation Awards - a force for conservation}

'There are people in this world - one hoped they had become extinct but they still exist - people who really think that conservationists and industrialists are locked in headlong battle, that it is immoral in some kind of way that they should talk to one another, let alone have any clue of one another's attitudes and beliefs.'

Sir David Attenborough used these words to open his address at the BP Conservation Awards ceremony on 26 April in London.

Those who read Mark Rose's column in the April issue of Fauna \& Flora News will know that we welcome opportunities to collaborate with companies that believe that it is possible to be both commercially effective and environmentally responsible. $\mathrm{BP}$ is such a company and the BP Conservation Awards are an excellent example of how such an approach can bring long-term benefits to wildlife conservation, to local communities and to expedition teams of young people.

The awards grew out of a recognition that traditional undergraduate expeditions visiting developing countries could make a valuable contribution to conservation if given guidance and assistance from conservation organizations. In 1988 BirdLife International and FFI joined forces to run a Conservation Expedition Competition and in $1990 \mathrm{BP}$ agreed to collaborate, injecting a substantial amount of money to enable the project to develop and grow.

Teams of young people submitting projects for awards must address an issue of international conservation importance as well as demonstrate local counterpart involvement and host-country acceptance. These criteria aim to increase the long-term, sustained conservation gain of a project by focusing the research objectives and building vital collaboration between personnel at all levels, from the project team and local people to government staff. BP, BirdLife International and FFI have all been delighted in what has been achieved over the last 5 years: numbers of applicants have risen; the scope has become more truly international, with teams from countries around the world applying; the quality of applications has improved; the level of involvement of local communities and local counterparts in the teams has increased; and, most important of all, conservation gains have been tremendous. Details of the winning expeditions will appear in the October issue of Fauna \& Flora News.

Team members usually benefit enormously from their involvement in an expedition, despite the hardships. They return with the satisfaction of a job well done and an enhanced understanding of conservation and how it affects local people in developing countries. Things do not always run smoothly, however, despite months of careful planning, training and attention to security. There is always an element of the unforeseen. The members of one of last year's winning teams, Lorentz 1995, an Anglo-Indonesian conservation expedition to survey the flora and fauna of a proposed World Heritage Site in the mountains of Irian Jaya, made headlines in the world's press when they were among 26 people captured on 8 January by the Free Papua Movement, which is seeking independence for Irian Jaya.

Most of the captives were soon released during negotiations involving the Red Cross, but the Lorentz team was among 11 people kept as hostages and the next 4 months were extremely worrying for the families, friends and organizations involved. Daily bulletins from Indonesia kept us informed of progress in negotiations for the release of the hostages and there was immense relief when we received news that nine hostages had been freed by the Indonesian Special Forces on 15 May. They included the four British members of Lorentz 95 - Daniel Start, Bill Oates, Annette van der Kolk and Anna Mclvor - and three Indonesian members - Adinda Saraswati, Julita Tanasale and Markus Warip. The relief was tempered with much sadness when we heard that two other Indonesian members of the team - Navy Panekenan and Yosias Lasamahu had been killed. Our deep sympathy goes to their families and friends.

Jacqui Morris, Editor 